which admits the force of mitigating circumstances-how invidious the task of the Secretary of State in dispensing the mercy of the crown-how critical the comments made by the public-how soon the object of general horror becomes the theme of sympathy and pity - how narrow and how limited the examples given by this condign and awful punishment-how brutal the scene at the execution-I come to the conclusion that nothing would be lost to justice, nothing lost in the preservation of innocent life, if the punishment of death were altogether abolished.

"In that case a sentence of a long term of separate confinement, followed by another term of hard labour and hard fare, would cease to be considered as an extension of mercy. If the sentence of the judge were to that effect, there would scarcely ever be a petition for remission of punishment, in cases of murder, sent to the Home Office. The guilty, unpitied, would have time and opportunity to turn repentant to the Throne of Mercy."

\title{
Dr. Symonds on Medical Evidence in Relation to State Medicine.
}

AFTER a learned and highly interesting lecture on certain points of the English language, delivered at the Bristol Insticution, by the Rev. J. Earle, formerly Professor of Anglo-Saxon at Oxford, a vote of thanks to the lecturer was proposed by a legal friend, a gentleman not more eminent by the high office which he holds, than distinguished by the ability and philanthropic zeal with which he has instigated various social reforms. In the course of some most valuable remarks on language, he said that those spoke best, and with most clearness and precision, who thought least of the effect which what they were saying would produce upon their hearers; and he declared that it was the want of such unconsciousness that made medical witnesses the worst of all witnesses in courts of law. And he clenched his remarks by alluding with playful malice (seeing that many of his medical friends were present) to a very sarcastic account of medical evidence in cases of lunacy with which a Lord Chancellor amused the House of Lords a few years ago. It happened to be my duty to second the vote of thanks; and I should have been a recreant, had I not availed myself of the opportunity of endeavouring to wipe away the aspersions cast by my learned friend on the character of medical witnesses. I ventured to say that, whatever psychological or philological truth there might be in the remark that a speaker should be free from self-consciousness or thought in regard to the effect of his words, yet my learned friend had omitted to mention the chief cause of the disadvantageous figure made by medical witnesses, which was, that they had to speak of things about 
which their audience, including the simple-minded jurors, the quickwitted gentlemen of the bar, and even the august occupants of the bench, were profoundly ignorant; and, moreover, that such witnesses had to translate as they were speaking, to put aside the language in which their professional knowledge and ideas most naturally flowed, and to accommodate what they had to say not only to the uninstructed understanding of their hearers, but also to the vernacular language; that, in the course of this process, much might be lost both of force and accuracy; and that the process required some presence of mind, especially under cross-examination, which mental quality was not likely to be aided by a severe injunction from the bench to give a plain answer to a plain question, or by an ironical petition from counsel that the witness should for the time being disencumber himself of his superflous learning, and condescend to the language of ordinary mortals. And, as to the allusion to the Lord Chancellor's mocking description of medical evidence, I could only say that, till I read his lordship's speech, I did not think that even a Iord Chancellor could, upon a medical subject, display so singular a lack of information. After the meeting, my friend told me that what I had said was not only fair in the way of retort upon an antagonist, but also that it was strictly and literally true.

There is one kind of evidence which is being continually demanded of a medical man in respect to the administration of the law, which, although it is not given in a court of law, may at any time be the means of taking him into it, and even of causing him to appear as a defendant or culprit rather than as a witness. I refer to certificates of insanity. On this subject, I confess that I marvel at the long suffering-I should almost say the stolid supineness, the pachydermatous patienco- of the profession. By these certificates we confer inestimable boons-first on the family of the patient, by separating a member whose presence is distressing and often absolutely dangerous to that family ; on the patient himself, by removing him to a place where he may have the best chance of cure, or be best cared for; and on the public, to whom the liberty of the patient might bring peril of life and prosperity. And for these services medical practitioners are liable to be held up to public scorn and obloquy as conspirators with mad doctors, as they are called by a vulgar and insulting metonymy, and even to be sued in courts of law for damages. How long the patience of the profession will allow itself to be thus abused, I know not; but it seems to me that, whether or not any other changes be effected in the collection of medico-legal evidence, the profession should, if it have any self-respect, move for a change in the law as to these certificates. If they are still to be signed by ordinary practitioners, it might not unreasonably be stipulated that indemnity should go with the signatures. In signing such a certificate, according to the best of his knowledge and belief and con-

voL. XI. 
science, - a certificate involving, though it does, the personal liberty of a fellow-subject, 一 the practitioner ought not to incur more risk than when he signs a prescription, on the issues of which attend not ouly the well-being and the life of the patient, but the maintenance of a family, its happiness, and that of circles of indefinite extent. The public have a sufficient security that such certificates will be carefully considered, in the disgrace that is the inevitable portion of those who have signed them in bad faith, or even without proper caution. Unless the law is altered, I think that the members of our profession would be justified in binding themselves by an engagement to one another, to refuse to sign all such certificates. The legislature could not compel us to sign them. Let it provide officers for that onerous and dangerous duty. But although by our passive resistance we could prevail, I trust that no such unseemly contention may be forced upon us.-British Medical Journal, Sept. 2nd, 1865.

\section{Dr. Lalor on Puerperal Insanity.}

"THE general proposition, then, as to the absence of danger to life, and the almost absolute certainty of recovery of reason in cases of acute puerperal insanity, attended by little disturbance of the circulation, as laid down by Gooch, agrees with my own experience. Further, abstracting these cases with serious complications from the entire nineteen cases under consideration, we have remaining sixteen cases of acute uncomplicated puerperal mania; and of these fifteen recovered and one died, being at the rate of $93 \frac{12}{60}$ ths per cent. of recoveries, and $6 \frac{4}{1}$ ths per cent. of deaths. I believe that at the present day there is no such prevalent belief amongst medical men as was held in Dr. Gooch's recollection (and indicated by the saying of Dr. Baillie which I have quoted), viz. :- 'That disorders of the mind in lying-in women are never fatal.' If any one retains such a belief, the results just stated are amply sufficient to disprove it, and my paper will not be entirely useless if it should remove a very serious error of opinion from the mind of a single practitioner of medicine, at the same time, if my later amended analysis, confined to cases of uncomplicated puerperal mania, offers a more legitimate deduction from fitting facts than that presented by my first statement, of the gross results in all cases, whether simple or complicated, a more hopeful view may be taken of the disease in that form which I believe was alluded to by Drs. Hunter and Gooch, in the propositions which I have brought under the notice of the society, than was put forward by those eminent authorities in these propositions. Nevertheless, acute puerperal insanity, occurring within 